\title{
Guidelines for landfill gas emission monitoring using the tracer gas dispersion method
}

\author{
Scheutz, Charlotte; Kjeldsen, Peter
}

Published in:

Waste Management

Link to article, DOI:

10.1016/j.wasman.2018.12.048

Publication date:

2019

Document Version

Peer reviewed version

Link back to DTU Orbit

Citation (APA):

Scheutz, C., \& Kjeldsen, P. (2019). Guidelines for landfill gas emission monitoring using the tracer gas dispersion method. Waste Management, 85, 351-360. https://doi.org/10.1016/j.wasman.2018.12.048

\section{General rights}

Copyright and moral rights for the publications made accessible in the public portal are retained by the authors and/or other copyright owners and it is a condition of accessing publications that users recognise and abide by the legal requirements associated with these rights.

- Users may download and print one copy of any publication from the public portal for the purpose of private study or research.

- You may not further distribute the material or use it for any profit-making activity or commercial gain

- You may freely distribute the URL identifying the publication in the public portal

If you believe that this document breaches copyright please contact us providing details, and we will remove access to the work immediately and investigate your claim 


\section{Guidelines for landfill gas emission monitoring using the tracer gas}

\section{2 dispersion method}

3

4 Charlotte Scheutz* and Peter Kjeldsen

5

6 Department of Environmental Engineering, Technical University of Denmark, DK-2800 Kgs.

$7 \quad$ Lyngby, Denmark

8

$9 \quad *$ Corresponding author

\section{Highlights}

- Regulation requires that landfill gas is managed, but monitoring guidelines are lacking

- Protocols to monitor landfill gas are given based on whole landfill emission measurements

- A guideline for best practice measurement performance using the tracer gas dispersion method

- Completion criteria for when monitoring activities can be terminated are set up and discussed

- Choosing completion criteria for termination is a political decision

\section{ABSTRACT}

Landfill gas often containing $50-60 \%$ methane, is generated on waste disposal sites receiving organic waste. Regulation requires that this gas is managed in order to reduce emissions, but very few suggestions exist as to how management activities are monitored, what should be set 
up to ensure this management and how criteria should be developed for when monitoring activities are terminated. Methane emission monitoring procedures are suggested, based on a robust method for measuring total leakage from the site; additionally, quantitative measures, to determine the efficiency of the performed emission mitigation, are defined. The tracer gas dispersion measuring technique is suggested as the core emission measurement methodology in monitoring plans for methane emissions from landfills and a guideline for best practice measurement performance is presented. A minimum methane mitigation efficiency of $80 \%$ is suggested. Finally, several principles are presented on how criteria can be developed for when a monitoring program can be terminated. Three of the suggested principles result in comparable completion criteria of about $1-3 \mathrm{~kg} \mathrm{CH}_{4} / \mathrm{h}$ for a small landfill (an area of $4 \mathrm{ha}$ ).

Keywords: waste disposal, methane emission, methane oxidation, mitigation efficiency, landfill gas monitoring, completion criteria,

\section{Introduction}

Landfill gas consisting primarily of methane (50-60\%) and carbon dioxide (40-50\%) is generated on waste disposal sites receiving organic waste as a result of biological, chemical and physical processes taking place in the landfill. The quality and quantity of emitted gas depend on several factors, such as waste composition and age, landfill design and maintenance routines, as well as local meteorological conditions. By setting up a detailed methane mass balance, a thorough understanding of methane gas generation and resulting transport, migration and emissions is obtained, which is fundamental for defining efficient mitigation approaches and connected monitoring plans.

The most important parts of the methane balance are shown in Fig. 1. Methane generated equals the sum of methane extracted, emitted into the atmosphere, oxidised, 
migrated laterally and stored internally in the landfill as follows:

$\mathrm{CH}_{4}$ generated $=\mathrm{CH}_{4}$ extracted $+\mathrm{CH}_{4}$ oxidised $+\mathrm{CH}_{4}$ emitted $+\mathrm{CH}_{4}$ migrated + $\Delta \mathrm{CH}_{4}$ storage (Eq.1)

4

The release of landfill gas into the environment can give rise to several environmental impacts, including contribution to climate change caused by emission of methane into the atmosphere. Controlling fugitive methane emissions from landfills should therefore be prioritised in waste management procedures. The Danish Landfill Directive (Miljøministeriet, 2011) prescribes that landfill gas should be managed by either gas collection and energy utilisation, by flaring or by other means, such as mitigation relying on microbial oxidation of the methane in cover soils or constructed biofilters (so-called 'biomitigation technologies'). The Danish Directive, which is very similar to the prescriptions in the European Union Landfill Directive (European Union, 1999), also states that landfill gas management should be properly monitored. Both the European and the Danish Directive provide very few details in respect to ways of carrying out the monitoring; there is especially scant focus on monitoring landfill gas emissions into the atmosphere or on the mitigation efficiency of implemented gas management schemes. In most cases, the efficiency of the implemented mitigation system such as gas collection or enhanced microbial oxidation in biocover systems is not evaluated, since emissions from the landfill are seldom measured.

Quantifying landfill methane emissions is a challenging task, due to spatial and temporal emission variations. Through the last 10-15 years, several new methane emission measurement techniques have been tested and demonstrated, and several newly dedicated instruments have entered the market. A recent review presents currently available measurement techniques and discusses advantages/disadvantages of the different approaches 
with reference to published literature on the subject (Mønster el al., 2019). Surface flux chambers have been used widely for landfill methane emission measurements, but they are likely to underestimate emission rates, due to the heterogeneous nature of most landfill covers and emissions from wells, vents, etc. not captured by flux chambers. The review suggests that accurate, whole-site emission quantifications are best done using methods measuring downwind of the landfill, such as radial plume mapping, tracer gas dispersion and DiAL (differential absorption lidar) (Mønster el al., 2019). By applying these measurement techniques, total methane emissions from the landfill are measured and thus the challenge with spatial emission variability is circumvented. The DiAL technique was identified as suitable for quantifying whole-site methane emissions, though the relatively high cost of the method was identified as a limitation for routine measurements (Mønster et al., 2019). The review identified the tracer gas dispersion technique as a suitable method for measuring an entire site's emission (Mønster et al., 2019) as well as a costefficient approach, which has been validated and its application demonstrated in several landfill studies. In addition to quantitative methods, qualitative reconnaissance techniques exist, such as surface emission screening by a handheld detector that is highly sensitive to low methane concentrations in ambient air. Qualitative reconnaissance techniques are valuable tools in the daily operation and maintenance of the landfill cover and of site installations such as gas collection and recovery systems.

With new technological capabilities for measuring methane emissions from landfills, there is a need to develop measurement plans and strategies to comply with current legislation as well as to document mitigation actions. Furthermore, there is a need to identify a lower methane emission limit value at which emission monitoring can be terminated.

The objective of this study was to develop best-practice emission monitoring plans for different landfill gas mitigation approaches, including suggestions for completion criteria for 
terminating monitoring activities. As a starting point, existing landfill monitoring plans were reviewed.

\section{Overview on previously published landfill emission monitoring and criteria}

Only a few international suggestions exist on landfill gas monitoring plans and criteria for terminating monitoring activity. A short summary of reports from Germany (Stegmann, 2006), Austria (Fellner \& Prantl, 2008), England (Environmental Agency, 2010), USA (Morris and Barlaz, 2011, Morris et al., 2012) and Australia (EPA Victoria, 2018a,b) is given below. Some of the details given are extracted from a review of approaches to the long-term management of municipal solid waste landfills (Laner et al., 2012).

Germany: Stegmann (2006) is one of the earliest and most concrete proposals for landfill methane emission monitoring and for when to terminate monitoring. The report proposes that active landfill gas emission mitigation should be carried out if gas production exceeds $25 \mathrm{~m}^{3} \mathrm{CH}_{4} / \mathrm{h}$ or $5 \mathrm{~m}^{3} \mathrm{CH}_{4} /(\mathrm{h} \cdot \mathrm{ha}$ ) (equivalent in mass units to $16 \mathrm{~kg} \mathrm{CH} / \mathrm{h}$ and $3.2 \mathrm{~kg}$ $\mathrm{CH}_{4} /(\mathrm{h} \cdot \mathrm{ha})$, respectively (the latter again corresponding to $7.7 \mathrm{~g} \mathrm{CH}_{4} /\left(\mathrm{m}^{2} \cdot \mathrm{d}\right)(\mathrm{STP} ; 1 \mathrm{~atm}$., $\left.0^{\circ} \mathrm{C}\right)$ ). If the gas produced is less than the above specified values, an assessment should be carried out to evaluate if landfill gas collection and utilisation are viable. Alternatively, it is proposed that mitigation activity should be established as methane oxidation in the final soil cover, thereby ensuring that the methane load to the final soil cover is less than $7.7 \mathrm{~g}$ $\mathrm{CH}_{4} /\left(\mathrm{m}^{2} \cdot \mathrm{d}\right)$ on average, and that methane concentrations above the soil cover are less than 25 ppm (measured by a sensitive, hand-held gas detector, such as a flame ionisation detector (FID)). It is proposed to conduct FID grid measurements at 16 per ha (a grid with a mask length of $25 \mathrm{~m}$ ), and thus the $80 \%$ quantile should not exceed $25 \mathrm{ppm}$. Measurements should be made twice a year (summer and winter). If this criterion is never exceeded over a 10 -year monitoring period, monitoring can be terminated. It should be noted that the abovementioned 
procedure was developed at a time when methods for measuring whole site emissions (such as the trace gas dispersion method) were not available, and that the presence of high-emission hotspot areas of very limited size had not yet been fully recognised (their existence shown by e.g. Fjelsted et al., 2019; Lando et al., 2017; Gonzalez-Valencia et al., 2016; Rachor et al., 2013, Scheutz et al., 2011a; 2011b; Bogner et al., 1997). The likelihood that such small hotspot areas will be identified by a hand-held gas detector in a 25-metre grid is very small. Methane production corresponding to a load of $7.7 \mathrm{~g} \mathrm{CH}_{4} /\left(\mathrm{m}^{2} \cdot \mathrm{d}\right)$ may be oxidised in the final soil cover - assuming that the cover, most of the time, has the ability to transport the gas (as controlled by the soil's permeability and diffusivity) and that the load is evenly distributed and not concentrated in high-loaded hotspot areas. Clay-type soils will rarely have sufficient gas permeability and diffusivities - especially in autumn and winter, when water content can be so high that gas transportation is not possible. In such cases, high gas pressures can build up within the waste volume and risk the formation of hotspot emission areas, resulting in low methane oxidation efficiency.

Austria: Proposed procedures from Austria are close to the above-described "Stegmann procedure" (Fellner \& Prantl, 2008). However, additional requirements are set up for emissions from the soil surface, which should be below $0.5 \mathrm{~m}^{3} \mathrm{CH}_{4} /(\mathrm{h} \cdot \mathrm{ha})$ (corresponding to $0.77 \mathrm{~g} \mathrm{CH}_{4} /\left(\mathrm{m}^{2} \cdot \mathrm{d}\right)$ or $10 \%$ of the "Stegmann value", and so at least $90 \%$ methane oxidation efficiency in the soil cover is anticipated. For a 4-hectare landfill site, the emission corresponds to $1.3 \mathrm{~kg} \mathrm{CH}_{4} / \mathrm{h}$. Criteria for terminating monitoring program are not mentioned.

England: England is probably the country with the longest record in setting up requirements to monitor methane emitted from landfills. The Environmental Agency for England has set specific requirements for methane emissions from landfills (Environmental Agency, 2010), which apply to both operating and closed sites. For those currently in operation, requirements exist for both the final covered and the temporarily covered stages. A 
temporary covered stage is defined as a stage that has not received waste for a period of 3 months or longer. In addition to making specific methane emission value requirements, specific requirements for monitoring, method, strategy, conditions and frequency of measurement are set up.

Monitoring of methane emissions is divided into two phases. The first phase (Phase 1) examines whether significant methane emissions are leaking from installations (e.g. gas and leachate collection wells) and from specific hotspots in the cover soil layer (e.g. cracks in the cover soil layer). A systematic walkover methane screening of the surface with a sensitive, hand-held gas detector, such as a FID, is performed. The sample probe should be held as close to the surface as possible $(<5 \mathrm{~cm})$, and the walkover survey of a zone should be along regular lines or transects. On a permanent cap, these transects are typically 50 metres apart, and on a temporary cap they are typically 25 metres apart. If high concentrations of methane are measured, the survey should deviate to locate the likely source of emission. Areas or installations with elevated methane concentrations are remediated before a follow up with Phase 2 monitoring, which involves quantitative methane emission measurements. The following requirements are set up for Phase 1 before it is possible to follow up with Phase 2 monitoring:

- Methane concentration in the air above the cover: $<100$ ppmv in the majority of the final covered area

- Methane concentration in the air close to the installations: $<1,000 \mathrm{ppmv}$

In the second phase (Phase 2), methane emissions from the cover soil layer (or the temporary cover layer) are measured by means of stationary flux chambers, whereby large numbers of measurements are performed in a selection of representative locations. Initially, the stages are divided into zones, the latter of which is defined as an area in which the cover is 
uniform and homogeneous. An average methane emission is calculated based on the performed flux measurements for each zone. Temporary covered stages must also be monitored, if they have been or are expected to be present at the site for a period of 12 months or longer. The temporary covered stages are also divided into zones. The number of flux chamber measurements depends on the area of the individual zones. For zones larger than $5000 \mathrm{~m}^{2}$, the number of measurements is calculated by $\mathrm{n}=6+0.15 \sqrt{ } \mathrm{Z}$, where $\mathrm{Z}$ is the area of the zone in $\mathrm{m}^{2}$ (Environmental Agency, 2010). Using this equation, 21 samples with an average spacing of 22 metres are needed to investigate a zone of 10,000 $\mathrm{m}^{2}$ (Environmental Agency, 2010). For smaller zones with an area of less than $5000 \mathrm{~m}^{2}$, the criterion for determining the number of locations is $\mathrm{n}=\left(\right.$ zone area $\left.\mathrm{m}^{2} / 5000 \mathrm{~m}^{2}\right) \cdot 16$ - albeit subject to a minimum of six locations. The following requirements apply for average methane emissions:

- Finally covered zones: $<0.001 \mathrm{mg} \mathrm{CH}_{4} /\left(\mathrm{m}^{2} \cdot \mathrm{s}\right)$ corresponding to $0.09 \mathrm{~g} \mathrm{CH}_{4} /\left(\mathrm{m}^{2} \cdot \mathrm{d}\right)$

- Temporary uncovered zones: $<0.1 \mathrm{mg} \mathrm{CH} /\left(\mathrm{m}^{2} \cdot \mathrm{s}\right)$ corresponding to $8.6 \mathrm{~g} \mathrm{CH}_{4} /\left(\mathrm{m}^{2} \cdot \mathrm{d}\right)$ The first monitoring (both including Phase 1 and Phase 2) should be performed within one year after the final cover is in place. If methane emissions exceed the prescribed emission requirements, measures have to be initiated to reduce them accordingly. Thereafter, a new round of measurements should be carried out, and if the average methane emission is within the acceptance criteria, follow-up monitoring can be performed as methane screening using a hand-held gas detector. If this is within the acceptance criteria for screening, methane emissions found in the former round of measurements should be reported. Additionally, there should be annual reporting of methane emissions to the authorities. Criteria for terminating monitoring programme are not mentioned.

The Environment Agency presented in 2012 guidance on how to surrender an environmental permit for a landfill, taking into account both landfill leachate and gas issues (Environment Agency, 2012). In respect to landfill gas, the permit may consist of monitoring 
gas flows and concentrations in bore holes. However, the procedures do not imply any methane emission measurements.

Recently, a newly proposed approach was presented for regulating English landfills, using a measured methane collection index $(\mathrm{MCI})(\mathrm{MCI}=$ collected methane $/$ (collected methane + methane emissions) (Bourn et al., 2019), which would involve an annual measurement campaign to quantify methane emissions and the use of the data provided by these surveys to develop an achievable but challenging MCI limit of 0.75 (Bourn et al., 2019). An MCI that falls below the limit would trigger actions to reduce methane emissions from the landfill.

USA: Morris et al. (2012) present a methodology for completing landfill gas management in the aftercare period, which is a further extension of the Evaluation of PostClosure Care (EPCC) methodology presented in Morris and Barlaz (2011), also including monitoring requirements for the control of methane emissions. The improved methodology takes into account the methane oxidation capacity of the cover system or the option of enhancing methane oxidation through engineered cover solutions. The methodology does not imply any measurement of methane emission measurement locally or for the whole site.

Australia: Very few guidelines in respect to landfill gas monitoring are issued in Australia, and only the state of Victoria has issued anything in this regard (EPA Victoria, 2018a) or for aftercare at closed landfills (EPA Victoria, 2018b). Most of the focus on landfill gas is about health issues and the risk of off-site gas migration to buildings and structures. The fugitive emission monitoring guideline is quite similar to the English guidelines (Environment Agency, 2010), with analysis of gas flow and concentrations in boreholes and walkover surveys using a sensitive methane measuring instrument, and an optional flux measuring approach using static flux chambers - similar to the English approach.

To summarise the international approaches presented above, it is clear that no 
approaches up to this point in time have incorporated whole-site methane emission measurements in the form of regulatory requirements - except for the new English approach presented by Bourn et al. (2019).

\section{Suggested emission monitoring approaches}

Methane emission monitoring should be carried out not only in the active period when waste is received at the site, but also in the aftercare period when waste is no longer received. Gas monitoring should be continued until significant methane emissions are no longer identified, even after implemented mitigation measures are terminated. What a significant methane emission is, or in other words what an appropriate completion criteria for monitoring activities is (for instance in tons $\mathrm{CH}_{4} /$ year), is highly debated, and no consensus has been reached. This question is dealt with in section 5 .

Based on information gathered from Danish landfills, the following six scenarios in respect to LFG mitigation approaches can be set up:

1. LFG is collected and utilised in a gas engine or other energy utilisation facility

2. LFG is collected and flared

3. LFG is collected and actively (by the use of pumps) led to a methane oxidising biofilter

4. LFG is led passively (without the use of pumps) to a methane oxidising biofilter

5. LFG is led passively (without the use of pumps) through the landfill top soil cover or biowindows

6. No established mitigation facilities. LFG quantity and fate are unknown.

In addition, several scenarios on different landfill cells within one landfill facility might exist, and there might also be cases where one scenario follows another (for instance establishing a biofilter (Scenario 3) when a gas extraction and flaring facility (Scenario 2) has 
become old and is no longer cost-effective).

Monitoring plans for the different scenarios (1 to 6) and ways of estimating mitigation efficiencies (Eq. 2 to 5) based on the methane balance approach for the landfill are described in the following.

In general, we suggest that mitigation efficiency should not be below $80 \%$, which admittedly is an ambitious but not unrealistic target considering the performance of the two mitigation technologies; gas collection and enhanced microbial oxidation in biocover systems. The mitigation efficiency of a gas collection and utilisation system depends on many factors, including the design and management of the system and the presence and type of top cover. Only relatively few studies reported in the literature have determined gas collection efficiencies from landfills using field measurements (Bourn et al. 2019; Rees-White et al., 2019; Agdam et al., 2018; Börjesson et al., 2009; Lohila et al., 2007; Spokas et al., 2006; Mosher et al., 1999), and well designed and operated gas collection systems have been shown to have efficiencies of $80 \%$ or higher (Bourn et al., 2019; Spokas et al., 2006; Mosher et al., 1999). However, at many landfills - especially older facilities - gas collection efficiency could be expected to be much lower (e.g. Bourn et al., 2019; Rees-White et al., 2019; Aghdam et al., 2018; Mønster et al., 2015; Börjesson et al., 2009; Lohila et al., 2007). Experience with full-scale landfill biocover systems for methane mitigation is still limited; however, a passively operated full-scale biocover system implemented at Klintholm landfill, Denmark, showed a mitigation efficiency of above $80 \%$ (Scheutz et al., 2014). Similarly a large pilot scale biocover at Denmark's AV Miljø landfill, actively loaded with landfill gas, showed an efficiency rate of more than 90\% (Scheutz et al., 2017).

Additional monitoring plans and measures are suggested in case the required mitigation efficiency is not met, which could be done by additional surface methane screening to identify significant release points or areas. Any identified major leaks should be repaired. 

measurement methodology in monitoring plans for methane emissions from landfills, in combination with initial methane emission screening efforts - for all mentioned scenarios. The tracer gas dispersion method and a guide to best practice are described in section 4 . In general, it is suggested that the whole site methane emission is measured twice a year; once in summer and once in winter to cover seasonal variability. Two annual measurements were found practically and economically achievable for the landfill operator. Due to influences of changing environmental conditions and changes in the landfill operation on methane emission rates, the measurements should be carried out under stable atmospheric conditions and normal landfill operation as described in section 4 .

The following three subsections provide details on the suggested monitoring plans, following the six scenarios identified in respect to the mitigation approaches mentioned above.

\subsection{Monitoring - at sites where landfill gas is collected (Scenarios 1-3)}

- Gas collection is calculated based on recorded landfill gas flow $\left(\mathrm{m}^{3} / \mathrm{h}\right)$ and methane content (\%vol.) recalculated to $\mathrm{kg} / \mathrm{h}$

- The emission of methane from the landfill is measured using the tracer gas dispersion method (or similar method) - initially twice a year (summer and winter)

- Mitigation efficiency, E, $(\%)$ is calculated:

$$
E=100 \% \cdot \frac{\mathrm{CH}_{4, \text { collected }}}{\left(\mathrm{CH}_{4, \text { collected }}+\mathrm{CH}_{4, \text { emitted }}+\mathrm{CH}_{4, \text { oxidised }}\right)}
$$

- Since quantification of the overall degree of methane oxidation at the landfill is challenging, we recommend to neglect oxidation $\left(\mathrm{CH}_{4}\right.$, oxidised $\left.=0\right)$. At some landfill sites, it released from hotspots, leachate wells, etc. For landfills where the emission mainly occurs 

estimate $\mathrm{CH}_{4, \text { oxidised }}$ by measuring stable carbon isotopes in the raw landfill gas and in the emitted gas. This method is currently in development.

- If the calculated mitigation efficiency (E) is lower than $80 \%$, supplementary monitoring and measures to optimise the mitigation system must be initiated.

305

3.2 Monitoring - at sites with passive gas supply via a gas collection/distribution system to

- The supply of landfill gas to the biofilter is shortly disconnected resulting in free release of the gas into the atmosphere

- The emission of methane is measured using the tracer gas dispersion method (or similar method) during both free landfill gas release and normal operation - and initially twice a year (summer and winter)

- Mitigation efficiency, E, (\%) is calculated:

$$
E=100 \% \cdot\left(1-\frac{\mathrm{CH}_{4, \text { emitted during normal operation }}}{\mathrm{CH}_{4, \text { emitted during free release to the atomsphere }}}\right)
$$

- If the calculated mitigation efficiency (E) is lower than $80 \%$, supplementary monitoring and measures to optimise the mitigation system are initiated.

3.3 Monitoring - at sites with passive supply of landfill gas to landfill soil cover/constructed

- It is assumed that the gas supply cannot be disconnected and the landfill gas vented to the atmosphere, since the gas is passively supplied to the cover/bio-windows

- Methane emission is measured using the trace gas dispersion method (or a similar method) during normal operation - initially twice a year (summer and winter) 
- It is preferred that methane emissions are measured prior to the establishment of the passive mitigation system (a baseline emission), ELSE

- Methane generation is estimated by using a landfill gas generation model (the Danish PRTR approach is recommended, Scheutz et al., 2009a)

- An estimate of mitigation efficiency, E, $(\%)$ is calculated:

$$
E=100 \% \cdot\left(1-\frac{\mathrm{CH}_{4, \text { emitted during normal operation }}}{\mathrm{CH}_{4, \mathrm{gene}} \text { rated (estimated via model) }}\right)
$$

or

$$
E=100 \% \cdot\left(1-\frac{\mathrm{CH}_{4, \text { emitted during normal operation }}}{\mathrm{CH}_{4, \text { emitted before established mitigation system })}}\right)
$$

- If the calculated mitigation efficiency (E) is lower than $80 \%$, supplementary monitoring and measures to optimise the mitigation system are initiated.

Changes in temporary storage of methane within the waste body were not considered in the suggested monitoring approaches and determination of mitigation efficiencies. The LFG gas pressure within landfills can vary due to temporal changes of cover gas permeability resulting from variation in precipitation and moisture content within the cover. Changes in atmospheric barometric pressure may lead to similar pressure changes on a much shorter time frame. Obviously also changes in LFG collection rates can lead to changes in temporary storage of methane - this can be of great importance especially at older landfills where the gas collection system is not operated continuously. Environmental and operational processes affecting landfill emissions are important to consider when planning or interpreting measured $\mathrm{CH}_{4}$ emissions at landfills. To reduce any influence of short term changes in methane stored in the landfill waste body we recommend that emission measurements are carried out under representative environmental and operational conditions would (also see section 4). 
"wild oxidation") was not considered. The main primary reason for excluding methane oxidation from the suggested monitoring approaches and determination of mitigation efficiencies is the difficulty in reliably and cheaply measuring the rate of oxidation across whole landfills. The IPCC suggests a default value for methane oxidation of $10 \%$ (IPCC, 2006). For some Danish landfills this value might be appropriate e.g. at landfills covered with clayey soils and where LFG mainly migrates through the leachate collection system (e.g. Scheutz et al., 2011a; 2011c), whereas at other Danish in particular older landfills the methane oxidation might be much higher (e.g. Christophersen et al., 2001). However, until accurate methods for determination of in-situ landfill methane oxidation becomes available (e.g. stable carbon isotopic analyses) this term is neglected.

\section{The tracer gas dispersion method and best practice} function of the ratio of the integrated cross-plume concentration of the emitted methane and

\subsection{Introduction and status}

The tracer gas dispersion (TGD) method is a ground-based remote sensing method used for quantifying fugitive emissions by relying on the controlled release of a tracer gas at the source, combined with concentration measurements of the tracer and target gas plumes (Fig. 2). The TGD method in general is based on the assumption that a tracer gas released at an emission source, in this case a landfill, will disperse in the atmosphere in the same way as methane emitted from the landfill will disperse. Assuming a defined wind direction, well mixed air above the landfill (causing the emitted methane and released tracer gas to be mixed fully) and constant tracer gas release, the methane emission rate can be calculated as a the integrated cross-plume concentration of the released tracer gas (Mønster et al., 2014; 2015; Scheutz et al. 2011). 
New developments in analytical technology have become powerful tools for quantifying methane emissions from landfills. A novel analytical approach has recently been implemented enabling mobile measurements of small changes (ppb level) in atmospheric methane and acetylene tracer gas concentrations, using a mobile high-resolution analytical instrument (Mønster et al., 2014; 2015; Roscioli et al., 2015). The TGD method has been applied in several studies for quantifying methane not only from landfills (e.g. Rees-White 2019; Fredenslund et al., 2019b; Mønster et al., 2015; 2014; Foster-Wittig et al., 2015; Börjesson et al., 2009), but also from other area sources such as natural gas facilities (e.g. Mitchell et al., 2015), biological waste treatment facilities (e.g. Andersen et al., 2010; Jensen et al., 2017; Reinelt et al., 2017) and wastewater treatment plants (e.g. Delre et al., 2017; Yoshida et al., 2014). The Danish Environmental Protection Agency currently recommends the use of TGD for landfill methane emission quantification, resulting in the method being routinely applied (DEPA, 2016). The United States Environmental Protection Agency also promotes TGD development (designated an EPA Category C "other test method" (OTM) 33B) as a standard method for plant-integrated and area source emission measurements (Foster-Wittig et al., 2015).

Several controlled release tests have been carried out to assess the accuracy of the tracer gas dispersion method (Mønster el at. 2014; Delre et al., 2018; Fredenslund et al., 2019a). Following best practice when performing measurements, the overall error of a TGD measurement is less than 20\% (Mønster el at. 2014; Delre et al., 2018; Fredenslund et al., 2019a). However, if the source is not correctly simulated by the tracer gas release, larger errors can be seen.

\subsection{Guideline for best practice}

A guideline for best practice measurement performance using the tracer gas dispersion 
method has been developed (Kjeldsen and Scheutz, 2015) and is described in the following.

Preliminary desktop study of the landfill. Before a measurement campaign, a desk study should be performed. The landfill is investigated in terms of its physical design (area, waste cells, leachate wells, gas collection facilities, presence of other activities at the landfill, e.g. composting, sludge treatment), following which information about gas collection system operation should be collected (duration and collected amounts of gas). The desk study should identify potential gas emission areas/sources and potential roads/paths for the on-site screening. The facility's surroundings must be carefully investigated in order to identify possible drivable roads that can be used for plume traversing, and there must be drivable roads at a distance away from the landfill corresponding to approximately five times the width of the landfill, with no disturbing methane sources (stables, biogas plants, sewage treatment plants, etc.) between the landfill and the monitoring road. In addition, optimal wind conditions (primary wind direction) are mapped relative to possible roadways.

Planning of the measurement campaign. The measurement campaign should be carried out when the wind blows in a preferable direction identified during the preliminary study. Additionally, stable weather conditions are preferred, due to the lower vertical atmospheric dispersion of gases and a consequently better plume definition within a traverse compared to measurements performed during unstable weather conditions. At landfills with low methane emissions, measurements during the night or with overcast weather, and thus the absence of solar radiation, are recommended. Measurements should be performed in weather conditions that allow for the continuous movement of air in the atmosphere, with wind speeds of 2-5 $\mathrm{m} \mathrm{s}^{-1}$ preferable (Mønster et al., 2014) in this regard. Furthermore, atmospheric pressure should be stable at around average pressure for the area. Measurements are not affected by rain or snow. 

out whereby the vehicle carrying the analytical instrumentation is driven around to measure atmospheric concentrations of methane and tracer gases on the landfill itself, at the edge of the landfill as well as in the area around the landfill. Emitting areas/sources are identified by comparing downwind and upwind concentrations of the detected gases. The purpose of on-site screening is to identify possible emission areas/sources, in order to position the tracer gas bottles so that the tracer release simulates methane emissions from the landfill as best as possible. The off-site screening performed in the surrounding area is aimed at investigating possible interfering methane sources between the landfill and the measurement road where the plume will be traversed, as well as off-site sources located upwind of the landfill. During off-site screening, an upwind background methane measurement is done. If there is limited access to the landfill (i.e. few drivable roads), a sensitive handheld detector can be used to locate and/or check potential emission pathways, for example areas with vegetation damage, cracks in the cover layer, slopes, leachate wells, etc. During the whole measurement when estimating the detection limit, which is site- and campaign-specific (Delre et al., 2017). magnitude) and the distance to the quantification road, several tracer gas-releasing points can be set. The tracer gas should be released so it represents the emission pattern of the facility,

442 i.e. releasing points should be placed at the most important on-site emitting sources.

443 Typically, two to five bottles are sufficient with a total trace release of typically $1-2 \mathrm{~kg} \mathrm{~h}^{-1}$.

444 The target gas-releasing rate should be known and constant over the quantification phase, thereby controlled, for example, by calibrated flow meters. An additional control over the released tracer gas should be performed by continuously monitoring the weight loss of the 
tracer gas cylinders. If a continuous record is not possible, the weight of the cylinders should be measured before and after the tracer gas-releasing period. A release of $0.5 \mathrm{~kg} \mathrm{~h}^{-1}$ tracer gas will provide a stable release over a period of at least 4 hours when using standard $21 \mathrm{~L}$ acetylene bottles.

Quantification phase. The plume should always be traversed at a distance that simultaneously allows for the proper mixing of methane and the tracer gas, and a proper plume distinction from the background concentration within the plume traverse. If real-time downwind measurements show that methane and target gas concentrations do not follow each other within the plume traverse, the tracer gas does not correctly simulate emissions of the target gas. In this case, either the tracer gas-releasing points can be changed or the plume could be traversed at a distance further away, to improve the mixing of methane and tracer gases. A plume traverse is considered successful if methane and the tracer gas follow each other when describing the plume, and the plume is completely crossed, thus the background concentration of methane and tracer gases can be identified on both sides of the plume. a minimum of 10 successful plume traverses should be collected (Mønster et al., 2014; Fredenslund et al., 2019a). After completing plume traversing, the tracer gas release bottles are turned off and the upwind background methane concentration measurement is repeated.

Data processing. Only successful plume traverses are used for calculating the landfill methane emission rate. For each plume traverse, the methane emission rate is obtained by multiplying three factors: the tracer gas mass release rate, the downwind concentration ratio of methane and tracer gas and the ratio of methane and tracer gas molecular weights. The methane-to-tracer gas ratio is found by integrating the plume concentrations of each gas in 
above plume baseline are included in the integration and ratio calculations. The plume baseline is found as the average of the concentrations on each side of the plume (the average of the concentrations measured in the background). The methane emission rate of one measurement campaign is reported as the average emission rate, calculated using all successful plume traverses, and the standard error of the mean is used to estimate uncertainty. An estimation of the lowest detectable emission rate for a specific measurement campaign can be calculated by using inverse Gaussian plume modelling (Delre et al., 2017).

Meteorological factors and monitoring conditions. Landfill emission measurement campaigns should be performed in conditions representative of normal landfill operation (e.g. normal gas management) and under representative environmental conditions. Data on the routine operation of the system should be collected to confirm that monitoring coincided with normal site conditions. Sampling performed during atypical periods may prove invalid for assessing compliance against emission standards. Landfill methane emissions can be influenced directly by the meteorological conditions prevailing before and during the monitoring period, especially changes in barometric pressure, wind speed and rain. When barometric pressure falls or is below the norm for that area, methane fluxes can be higher than normal, and vice versa. Ideally, measuring campaigns should be conducted during periods when the change in barometric pressure is less than \pm 3 mbar from the pressure norm for the area, measured 6 hours prior to the campaign to the end of the campaign. Heavy rain can reduce the permeability of the landfill cover soil, and so campaigns should be avoided 492 following periods of unusually substantial precipitation. Performance of emission measurement under representative environmental and operational conditions would reduce any influence of short changes in methane stored in in the landfill waste body. 

record total emissions from the site according to downwind plume concentration measurements, such as the tracer gas dispersion method described above. Alternatively, the radial plume method or the DiAL method could be used (Mønster et al., 2019). The radial plume method is associated with a number of disadvantages (e.g. limited laser path length, limited application in complex topographies, laborious, etc.), which has led to less frequent use in recent years. In some instances, the method has been replaced by tracer gas dispersion or DiAL. New measurement techniques applying the mass balance approach but using atmospheric concentration measurements across the downwind plume at several heights from aircrafts or unmanned aerial vehicles (UAVs) are under development. The measured concentrations are then used to create a two-dimensional concentration plane, which is used together with measured wind speed and direction for calculating the flux of methane through the downwind plane (e.g. Allen et al., 2018; Cambaliza et al., 2015; 2017). Accurate instruments for methane concentration analysis at the ppb level are currently too heavy to employ in a UAV, and aircraft-based measurements are still done mainly in the oil and gas sector. However, the fast development within both sensors and UAVs could soon allow the use of UAVs for measuring landfill methane emissions with accuracy and spatial and temporal resolution.

\section{Criteria for terminating emission monitoring}

A monitoring plan should contain a description of when it is safe to terminate monitoring activities. The description should be quantitative and concrete in the form of a completion criterion for the emission (depicted in $\mathrm{kg} \mathrm{CH}_{4} / \mathrm{h}$ or tons $\mathrm{kg} \mathrm{CH}_{4} / \mathrm{y}$ ). It is not only well-known that landfill gas generation can continue for several decades, but also that the generation rate decreases steadily over time, during which the "natural" oxidation of methane 
522 (intentional or unintentional oxidation taking place in the landfill soil cover) is more 523 significant (due to longer gas retention times in the cover), which may decrease methane 524 emissions even further. On the other hand, it is unrealistic to expect a state of zero emissions, 525 since there will always be localised areas with sub-optimal conditions for methane oxidation 526 from which emissions may occur. In the following, we give an overall discussion on 527 principles for setting completion criteria, and it is not our idea to only suggest principles, which comply with existing European legislation. The discussion focuses solely on gas monitoring and do not include discussion on when an overall surrender of the landfill is reached, taking into account other environmental aspects such as leachate infiltration to groundwater.

Four different principles for establishing completion criteria for methane monitoring were identified:

1. Gas generation can be mitigated passively by "natural" methane oxidation in the final soil cover

2. The measured whole-site methane emission is lower than the detection limit of the tracer gas dispersion methodology (or an alternative measuring method for whole-site methane emission monitoring)

3. The whole-site methane emission (per unit surface area) is lower than similar surface area normalised emissions from natural ecosystems (wetlands)

4. Costs for continued mitigation will be much higher than mitigation costs in other societal sectors (measured in $€ /$ tons $\mathrm{CO}_{2}$-equivalents).

\subsection{Passive methane oxidation in the final soil cover}

At a certain time, it can be expected that gas generation will be so low that passive handling based on methane oxidation in the final soil cover will reduce methane emissions to 
an acceptably low level - even taking into account a certain spatial variability in the gas loading to the final soil cover. When existing activities for mitigating methane emissions are based on the active extraction of gas, the gas engine (or similar) can be bypassed for a short period during which total methane emissions from the site are measured (as described in the previous section). Based on the measured methane emission rate, an area-distributed methane load can be evaluated (assuming that the total area of the final soil cover is known, and assuming an evenly distributed methane load to the cover). If the average load of methane is loading, which means that the release of methane from the landfill will be a maximum of 1 $\mathrm{g} /\left(\mathrm{m}^{2} \cdot \mathrm{d}\right)$ or less. High methane oxidation in the cover layer assumes that the soil used for the cover layer has sufficiently high gas permeability/diffusivity for the gas to be transported through the soil cover. Soil covers on many landfills often contain clayey soils (in order to reduce the infiltration of excess precipitation), which, over large periods of the year, will exhibit high water content, thereby leading to very low gas permeability as well as low gas diffusivity, resulting in high resistance towards gas transport. Instead, the gas will find its way to areas with higher gas permeability, leak through installations such as leachate wells or - if possible - migrate to the surrounding areas containing soils of higher gas permeability. Before active mitigation activities are shut down, it is important to ensure that the gas can be transported through the final soil cover. To test whether the covering layer can actually reduce methane present after the closure of mitigation activities, monitoring should be carried out before and after shutdown (at least one measurement of the site's total methane emissions after closure should be performed). The measurement may in this case reveal that methane emissions are unacceptably high $\left(>1 \mathrm{~g} /\left(\mathrm{m}^{2} \cdot \mathrm{d}\right)\right)$. As a consequence, this may imply that existing mitigation activities must be continued for some time yet, or alternatively that bio-

571 windows designed for optimising methane oxidation are established in areas with a low- 
572 permeable soil cover. For a landfill with an area of 4 ha, a completion criterion of $1 \mathrm{~g} /\left(\mathrm{m}^{2} \cdot \mathrm{d}\right)$ 573 corresponds to a methane emission of $1.6 \mathrm{~kg} \mathrm{CH}_{4} / \mathrm{h}$.

\subsection{Total methane emission lower than detectable limits}

As already stated, it is recommend that the measurement of total methane emissions from a landfill is the core monitoring activity, and that the trace gas dispersion methodology is used. Detailed investigations using the methodology have shown that the detection limit for methane emissions measured with a state-of-the-art version of the methodology is about $1 \mathrm{~kg}$ $\mathrm{CH}_{4} / \mathrm{h}$ (Mønster et al., 2014; Fredenslund et al. 2019b). If total methane emissions are lower than this value, it becomes difficult to prove that the landfill is indeed emitting methane into the environment. A completion criterion could be that the emission must be less than $1 \mathrm{~kg}$ $\mathrm{CH}_{4} / \mathrm{h}$ for the landfill, which would be achieved after shutting down all active mitigation actions at the site. For a landfill with an area of 4 ha, this corresponds to a methane emission of $0.6 \mathrm{~g} \mathrm{CH}_{4} /\left(\mathrm{m}^{2} \cdot \mathrm{d}\right)$.

\subsection{Total methane emissions equivalent to emissions from natural ecosystems}

Landfills are globally one of the most important anthropogenic sources of methane emission (Bogner et al., 2008). On a global scale, methane emissions from landfills are estimated to account for about $8 \%$ of all anthropogenic methane emissions (Blanco et al., 2014). Besides anthropogenic sources, there are several natural methane sources such as lakes, rivers, wetlands, etc. Methane emissions from natural sources are generally unregulated and could therefore be a reference for emissions from anthropogenic sources. It might be argued that there should not be stricter emission limits for anthropogenic sources (e.g. normalised per unit area) than for typical emissions from natural sources. One scientific article (Ortis-Llorente \& Alvarez-Cobelas, 2012) reviewed the literature on methane 
emissions from natural sources, finding average annual methane emissions from wetlands (defined in the article as "sites where water is at or near the soil surface for a significant part of the growing season") of $470 \mathrm{~g} \mathrm{CH}_{4} /\left(\mathrm{m}^{2} \cdot \mathrm{y}\right)$ - equivalent to $1.3 \mathrm{~g} \mathrm{CH}_{4} /\left(\mathrm{m}^{2} \cdot \mathrm{d}\right)$ - based on 126 references. For a landfill with an area of 4 ha, this corresponds to a methane emission of 2.2 $\mathrm{kg} \mathrm{CH} / \mathrm{h}$, which is of the same order as the above detection limit for the tracer gas dispersion method.

\subsection{Optimisation of societal expenses for mitigating greenhouse gas emissions}

Setting up a relatively low completion criterion for methane emissions will generally reduce the contribution made by landfills to climate change. However, it also means that mitigation activities must be maintained for many years in the after-care period, resulting in an overall low reduction during the period (measured in tons of reduced emissions of $\mathrm{CO}_{2}-$ equivalents). By documenting the cost of operating these mitigation activities (including the costs for maintaining and monitoring the mitigation activities), the resulting mitigation costs (in $€ /$ tonnes $\mathrm{CO}_{2}$-equivalents reduced) are calculated and compared with similar normalised prices for other mitigation activities carried out in society. Here, one can argue that there should be proportionality between the various initiatives. If the normalised cost for mitigation of methane emissions from a landfill is considerable higher than normalised costs for society's additional optional mitigation activities, it could be argued that landfill methane emission mitigation should be carried out no longer.

\subsection{Overview of the completion criteria}

The first three principles described above gave completion criteria in the order of $1-3 \mathrm{~kg}$ $\mathrm{CH}_{4} / \mathrm{h}$ for a small landfill (area of $4 \mathrm{ha}$ ), as shown in Table 1 . The last mentioned criteria can only be evaluated by additional economic evaluations and a political decision on the level of 
mitigation costs society wishes to pay.

623

624

\section{Conclusions}

625

The European Union Landfill Directive demands that gas generated at a landfill is properly managed and that monitoring plans are set up. However, the directive provides neither details on how gas monitoring plans should be devised nor recommends procedures for evaluation of how long gas monitoring should be carried out in the after-care period. Based on a review of existing suggested monitoring approaches from European countries, and an evaluation of existing methods for measuring total emissions from landfills, an emission monitoring approach is suggested. The validated tracer gas dispersion method is a core element in the approach and calculates quantitative mitigation efficiencies through different mitigation approaches. A minimum required mitigation efficiency of $80 \%$ is suggested, and measures to be taken, if the mitigation activities do not live up to requirements, are described. Finally, emission completion criteria for terminating a monitoring procedure are discussed and four different approaches presented. A final approach for termination is not given; however, a comparison of three different principles provides a completion criterion in the order of $1-3 \mathrm{~kg} \mathrm{CH}_{4} / \mathrm{h}$ for a small landfill (area of $4 \mathrm{ha}$ ).

\section{Acknowledgements} noted that the views given in this article do not necessarily reflect the position or opinions of the Danish Environmental Protection Agency. The contribution by Niels Jørgen Olsen, from the agency, is especially acknowledged.

\section{References}


Determination of gas recovery efficiency at two Danish landfills by performing downwind 220-229.

Allen, G., Hollingsworth, P., Khristopher Kabbabe, K., Pitt, J.R., Mead, M.I., Illingwort, S.,

Roberts, G., Bourn, M., Shallcross, D.E., Percival, C.J., 2018. The development and trial of greenhouse gas emission hotspots. Waste Manage. In press. doi:10.1016/j.wasman.2017.12.024.

Andersen, J.K., Boldrin, A., Christensen, T.H., Scheutz, C., 2010. Greenhouse gas emissions

Blanco G., Gerlagh, R., Suh, S., Barrett, J., de Coninck, H.C., Diaz Morejon, C.F., Mathur, Assessment Report of the Intergovernmental Panel on Climate Change [Edenhofer, O., PichsMadruga, R., Sokona, Y., Farahani, E., Kadner, S., Seyboth, K., Adler, A., Baum, I., Brunner, S., Eickemeier, P., Kriemann, B., Savolainen, J., Schlömer, S., von Stechow, C., Zwickel, T., Minx, J.C. (eds.)]. Cambridge University Press, Cambridge, United Kingdom and New York, NY, USA.

Bogner, J., Meadows, M., Czepiel, P., 1997. Fluxes of methane between landfills and the atmosphere: natural and engineered controls. Soil Use and Management. 13, 268-277. 
671 emissions from waste: conclusions and strategies from the Intergovernmental Panel on

672 Climate Change (IPCC) Fourth Assessment Report. Working Group III (Mitigation). Waste 673 Manage. Res. 26, 11-32.

674 Börjesson, G., Samuelsson, J., Chanton, J., Adolfsson, R., Galle, B., Svensson, B.H., 2009. A 675 national landfill methane budget for Sweden based on field measurements, and an evaluation 676 of IPCC models. Tellus B. 61, 424-435.

677 Bourn, M., Robinson, R., Innocenti, F., Scheutz, C., 2019. Regulating landfills using 678 measured methane emissions: An English perspective. Waste Manage. In press. 679 doi:10.1016/j.wasman.2018.06.032.

680 Cambaliza, M.O.L., Bogner, J.E., Green, R.B., Shepson, P.B., Harvey, T.A., Spokas, K. A., 681 Corcoran, M., 2017. Field measurements and modeling to resolve $\mathrm{m}^{2}$ to $\mathrm{km}^{2} \mathrm{CH}_{4}$ emissions 682 for a complex urban source: An Indiana landfill study. Elementa: Science of the 683 Anthropocene, 5, 36.

684 Cambaliza, M.O.L., Shepson, P.B., Bogner, J., Caulton, D.R., Stirm, B., Sweeney, C., 685 Richardson, S., 2015. Quantification and source apportionment of the methane emission flux 686 from the city of Indianapolis. Elementa: Science of the Anthropocene, 3, 37.

687 Christophersen M., Kjeldsen P., Holst H., Chanton, J., 2001. Lateral gas transport in soil 688 adjacent to an old landfill: factors governing emissions and methane oxidation. Waste 689 Manage. Res. 19, 595-612.

690 Delre, A., Mønster, J., Scheutz, C., 2017. Greenhouse gas emission quantification from 691 wastewater treatment plants, using a tracer gas dispersion method. Sci. Total Environ. 605692 606, 258-268. 
693

694

695

696

697

698

699

700

701

702

703

704

705

706

707

708

709

710

711

712

713

714

DEPA, 2016. Danish Environmental Protection Agency Website about Biocover project (accessed July 22, 2017) [WWW Document]. URL http://mst.dk/affald-

jord/affald/deponering/biocover-tilskudsordning/afrapportering-og-dokumentationskrav/

Environmental Agency, 2010. Guidance on monitoring landfill gas surface emissions. Report published by the Environmental Agency, UK.

https://assets.publishing.service.gov.uk/government/uploads/system/uploads/attachment_data /file/321614/LFTGN07.pdf. Accessed December 2018.

Environmental Agency, 2012. Additional guidance for Landfill (EPR 5.02) and other permanent deposits of waste. How to surrender your environmental permit. Bristol, UK, 30p.

European Union, 1999. Council Directive 1999/31/EC of 26 April 1999 on the landfill of waste. Official Journal of the European Communities, Luxembourg.

EPA Victoria, 2018a. Landfill gas fugitive emissions monitoring guideline. Publication 1684, Environment Protection Authority Victoria, Carlton, Victoria, Australia.

EPA Victoria, 2018b. Closed Landfill Guidelines. Publication 1490.1, Environment Protection Authority Victoria, Carlton, Victoria, Australia.

Fellner, J. Prantl, R. (Eds.), 2008. Konzeptionelle Überlegungen zur Entlassung aus der Deponienachsorge. ÖWAV-Positionspapier, Österreichischer Wasser- und Abfallwirtschaftsverband, 1010 Wien, Marc-Aurel-Straße 5. Österreich.

Fjelsted, L., Christensen, A.G., Larsen, J.E., Kjeldsen, P., Scheutz, C., 2019. Assessment of a landfill methane emission screening method using an unmanned aerial vehicle mounted thermal infrared camera - A field study. Waste Manage. In press.

doi:10.1016/j.wasman.2018.05.031 
Development of a mobile tracer correlation method for assessment of air emissions from landfills and other area sources. Atmos. Environ. 102, 323-330.

Fredenslund, A.M., Rees-White, T.C., Beaven, R.P., Delre, A., Finlayson, A., Helmore, J., Allen, G., Scheutz, C., 2019a. Validation and error assessment of the mobile tracer gas dispersion method for measurement of fugitive emissions from area sources. Waste Manage. In press. doi:10.1016/j.wasman.2018.10.036

Fredenslund, A.M., Mønster, J., Scheutz, C., Kjeldsen, P., 2019b. Development and implementation of a screening method to categorise greenhouse gas mitigation potential of 91 landfills. Waste Manage. In press. doi:10.1016/j.wasman.2018.03.005 detection and spatial distribution of methane emissions from landfills by a surface probe method. Waste Manage. 55, 299-305. emissions from a biological waste treatment facility. Waste Manage. 67, 375-384. doi: 10.1016/j.wasman.2017.05.033

Kjeldsen, P., Scheutz, C., 2015. Håndbog i monitering af gasemission fra danske affaldsdeponier (Handbook in monitoring of gas emission from Danish waste disposal sites, in Danish). København K: Miljøministeriet. Miljøstyrelsen. (Miljoeprojekter; No. 1646). point and scanning method to estimate spatial distribution of methane emission in landfill. Waste Manage. 59, 255-266. 
Laner, D., Crest, M., Scharff, H., Morris, J.W.F., Barlaz, M.A., 2012. A review of approaches for the long-term management of municipal solid waste landfills. Waste Manage. 32, 498512.

Lohila, A., Laurila, T., Tuovinen, J.-P., Aurela, M., Hatakka, J., Thum, T., Pihlatie, M., Rinne, J., Vesala, T., 2007. Micrometeorological measurements of methane and carbon dioxide fluxes at a municipal landfill. Environ. Sci. Technol. 41, 2717-2722.

Miljøministeriet (2011): The Danish landfill directive (Deponeringsbekendtgørelsen, in Danish, BEK nr 719 of 24/06/2011)

Mitchell, A.L., Tkacik, D.S., Roscioli, J.R., Herndon, S.C., Yacovitch, T.I., Martinez, D.M., Vaughn, T.L., Williams, L.L., Sullivan, M.R., Floerchinger, C., Omara, M., Subramanian, R., Zimmerle, D., Marchese, A.J., Robinson, A.L., 2015. Measurements of methane emissions from natural gas gathering facilities and processing plants: measurement results. Environ. Sci. Technol. 3219-3227.

Morris, J.W.F, Barlaz, M.A. 2011. A performance-based system for the long-term management of municipal waste landfills. Waste Manage. 31, 649-662.

Morris, J.W.F., Crest, M., Barlaz, M.A., Spokas, K.A., Åkerman, A., Yuan, L. 2012. Improved methodology to assess modification and completion of landfill gas management in the aftercare period. Waste Manage. 32, 2364-2373.

Mønster, J., Kjeldsen, P., Scheutz, C., 2019. Methodologies for measuring fugitive methane emissions from landfills - a review. Waste Manage. In press.

Mønster, J, Samuelsson J., Kjeldsen, P., Scheutz, C., 2014. Quantifying methane emission from fugitive sources by combining tracer release and downwind measurements - test, verification and documentation of the method. Waste Manage. 34, 1416-1428. 
Mønster, J., Samuelsson, J., Kjeldsen, P., Scheutz, C., 2015. Quantification of methane emission from 15 Danish landfills using mobile tracer dispersion method. Waste Manage. 35, $177-186$.

Ortiz-Llorente, M.J., Alvarez-Cobelas, M., 2012. Comparison of biogenic methane emissions from unmanaged estuaries, lakes, oceans, rivers and wetlands. Atmospheric Environment, 59, 328-337.

Rachor, I.M., Gebert, J., Gröngröft, A., Pfeiffer, E.-M., 2013. Variability of methane emissions from an old landfill over different time-scales. European Journal of Soil Science, February 2013, 64, 16-26.

Rees-White T.C., Mønster, J., Beaven R.P., Scheutz, C., 2019. Measuring methane emissions from a UK landfill using the tracer dispersion method and the influence of operational and environmental factors. Waste Manage. In press. doi:10.1016/j.wasman.2018.03.023

Reinelt, T., Delre, A., Westerkamp, T., Holmgren, M.A., Liebetrau, J., Scheutz, C., 2017. Comparative use of different emission measurement approaches to determine methane emissions from a biogas plant. Waste Manage. 68, 137-185.

Roscioli, J.R., Yacovitch, T.I., Floerchinger, C., Mitchell, A.L., Tkacik, D.S., Subramanian, R., Martinez, D.M., Vaughn, T.L., Williams, L., Zimmerle, D., Robinson, A.L., Herndon, S.C., Marchese, A.J., 2015. Measurements of methane emissions from natural gas gathering facilities and processing plants: measurement methods. Atmos. Meas. Tech. 8, 2017-2035. Scheutz, C., Cassini, F., Schoenmaeker, Jan De., Kjeldsen, P., 2017. Mitigation of methane emissions in a pilot-scale biocover system at the AV Miljø Landfill, Denmark: 2. Methane oxidation. Waste Manage. 63, 203-212. 
Scheutz, C., Pedersen R.B., Petersen, P.H., Jørgensen J.H.B., Ucendo, I.M.B., Mønster, J. G., Samuelsson, J., Kjeldsen, P., 2014. Mitigation of methane emission from an old unlined landfill in Klintholm, Denmark using a passive biocover system. Waste Manage. 34, 11791190.

Scheutz, C., Fredenslund, A.M., Nedenskov, J., Samuelsson, J., Kjeldsen, P., 2011a. Gas production, composition and emission at a modern disposal site receiving waste with a low organic content. Waste Manage. 31, 946-955.

Scheutz, C., Samuelsson, J., Fredenslund, A.M., Kjeldsen, P., 2011b. Quantification of multiple methane emission sources at landfills using a double tracer approach. Waste Manage. 31, 1009-1017.

Scheutz, C., Fredenslund, A.M., Chanton, J., Pedersen, G.B., Kjeldsen, P. 2011c. Mitigation of methane emission from Fakse landfill using a biowindow system. Waste Manage. 31, $1018-1028$.

Scheutz, C., Kjeldsen, P., Trolle, C., Scharff, H., 2009a. The Danish method for emission reporting to PRTR from waste disposal sites. In Sardinia 2009: Twelft International Waste Management and Landfill Symposium, 5-9 October, Sardinia, Italy. (Vol. Proceedings. CDROM, pp. 617). Cagliari, Italy: CISA, Environmental Sanitary Engineering Centre.

Scheutz, C., Bogner, J., De Visscher, A., Gebert, J., Hilger, H., Huber-Humer, M., Kjeldsen, P., Spokas, K., 2009b. Processes and technologies for mitigation of landfill gas emissions by microbial methane oxidation. Waste Manage. Res. 27(5), 409-455.

Spokas, K., Bogner, J., Chanton, J.P., Morcet, M., Aran, C., Graff, C., Golvan, Y.M. Le, Hebe, I., 2006. Methane mass balance at three landfill sites: What is the efficiency of capture by gas collection systems? Waste Manage. 26, 516-525. 
805 Stegmann, R., 2006. Deponienachsorge - Handlungoptionen, Dauer, Kosten und quantitative 806 Kriterien für die Entlassung aus der Nachsorge. FKZ 20434 327, Ingenieurbüro für 807 Abfallwirtschaft - Prof. R. Stegmann und Partner., Hamburg, Deutschland.

808 Yoshida, H., Mønster, J., Scheutz, C., 2014. Plant-integrated measurement of greenhouse gas 809 emissions from a municipal wastewater treatment plant. Water Res. 61, 108-118. 
812 Table 1. Overview of completion criteria for methane emissions based on different theoretical

813 principles. Additionally, acceptance criteria for monitoring plans reported in the literature

814 from different countries are shown.

\begin{tabular}{|c|c|c|c|}
\hline \multirow[t]{2}{*}{$\begin{array}{l}\text { Theoretical established completion } \\
\text { criterion }\end{array}$} & $\begin{array}{l}\text { Levels for methane supply to } \\
\text { cover soil layer }\end{array}$ & \multicolumn{2}{|c|}{$\begin{array}{c}\text { Completion criteria for methane } \\
\text { emission }\end{array}$} \\
\hline & $\mathrm{g} /\left(\mathrm{m}^{2} \cdot \mathrm{d}\right)$ & $\mathrm{g} /\left(\mathrm{m}^{2} \cdot \mathrm{d}\right)$ & $\mathrm{kg} / \mathrm{h}$ \\
\hline 1. Passive methane oxidation in soil cover & $16.5^{\mathrm{a}}$ & $1.0^{\mathrm{e}}$ & $1.6^{\mathrm{e}}$ \\
\hline $\begin{array}{l}\text { 2. Total methane emission lower than } \\
\text { detectable }\end{array}$ & n.d. & $0.6^{\mathrm{a}}$ & 1.0 \\
\hline $\begin{array}{l}\text { 3. Methane emission similar to emissions } \\
\text { from natural eco systems }\end{array}$ & n.d. & 1.3 & $2.2^{\mathrm{a}}$ \\
\hline $\begin{array}{l}\text { 4. Optimisation of expenses to mitigate } \\
\text { societies greenhouse gas emissions }\end{array}$ & c.s. & c.s. & \\
\hline \multirow[t]{2}{*}{ International suggestions } & $\begin{array}{l}\text { Acceptance levels for methane } \\
\text { supply to cover soil layer }\end{array}$ & \multicolumn{2}{|c|}{$\begin{array}{c}\text { Acceptance criteria for methane } \\
\text { emission }\end{array}$} \\
\hline & $\mathrm{g} /\left(\mathrm{m}^{2} \cdot \mathrm{d}\right)$ & $\mathrm{g} /\left(\mathrm{m}^{2} \cdot \mathrm{d}\right)$ & $\mathrm{kg} / \mathrm{h}$ \\
\hline Germany (Stegmann, 2006) & $7.7 \quad 12.7^{\mathrm{a}, \mathrm{b}}$ & & \\
\hline Austria (Fellner \& Prantl, 2008) & n.d. & 0.77 & $1.3^{\mathrm{a}}$ \\
\hline \multirow[t]{2}{*}{ England (Environmental Agency, 2010) } & & 0.09 & $0.15^{\mathrm{a}}$ \\
\hline & & $8.6^{\mathrm{d}, \mathrm{c}}$ & $14.3^{\mathrm{a}, \mathrm{c}, \mathrm{d}}$ \\
\hline
\end{tabular}




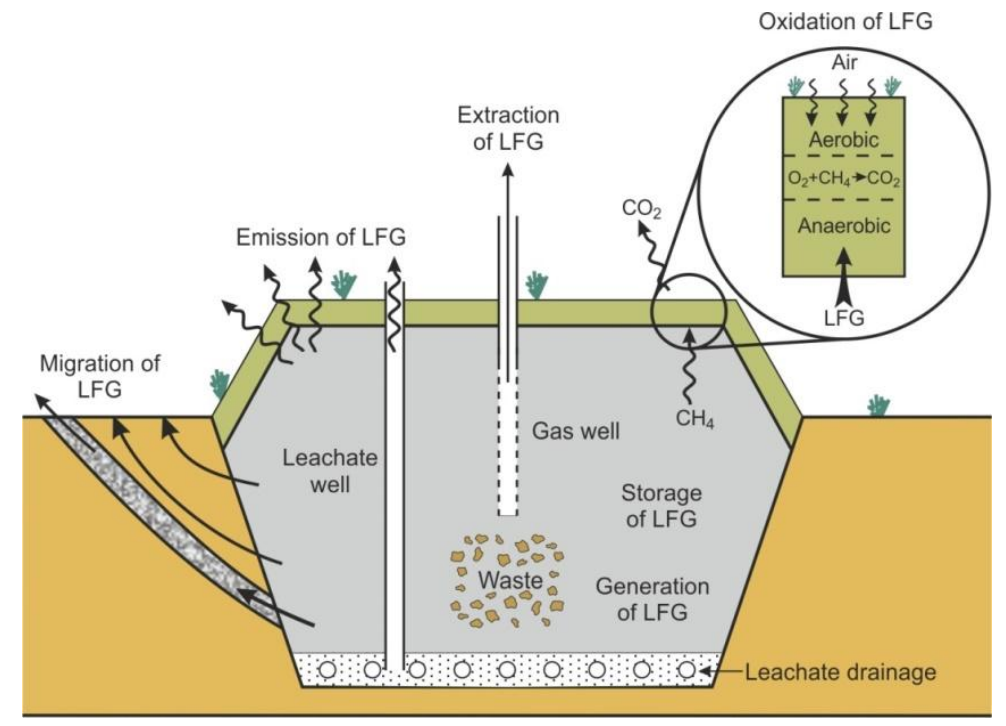

823 Fig. 1. Processes affecting the fate of methane generated in a landfill (adapted from Scheutz 824 et al., 2009b). 


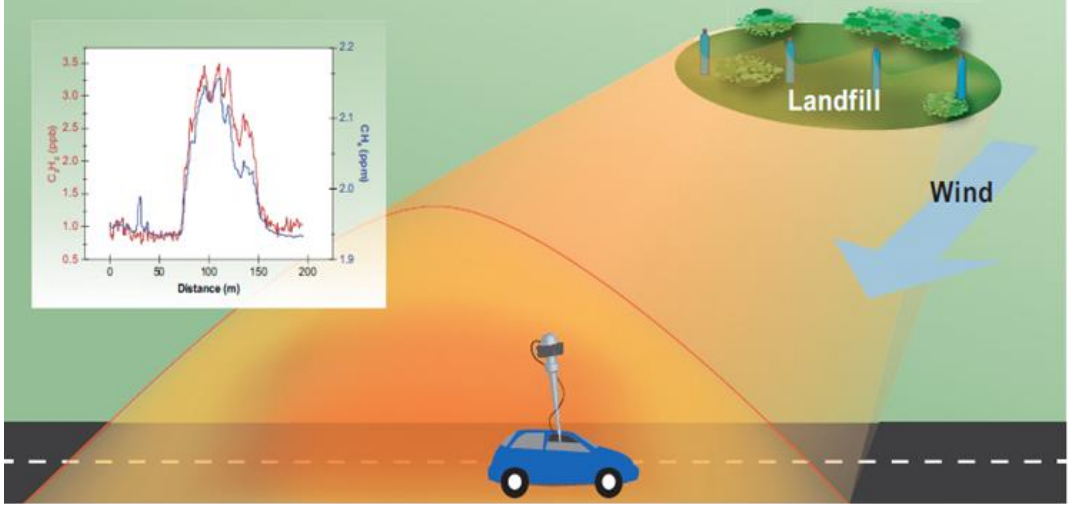

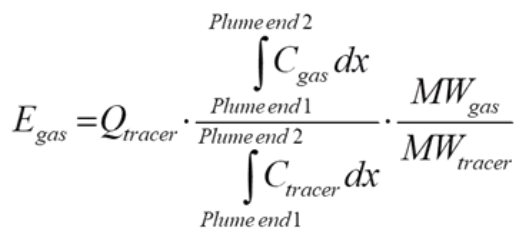

$E_{\text {gas }}$ : methane emission rate $\left(\mathrm{kg} h^{-1}\right)$,

$Q_{\text {tracer: }}$ tracer gas release rate $\left(\mathrm{kg} h^{-1}\right)$,

$C_{\text {gas }}$ and $C_{\text {tracer: }}$ : cross-plume

concentrations (ppb) above background, MW: molecular weights,

$x$ : distance across the plume.

829 Fig. 2. The tracer gas dispersion method for whole landfill methane emission quantification. 